\title{
Thinning and retreat of Glaciar Upsala, and an estimate of annual ablation changes in southern Patagonia
}

\author{
Renji Naruse, ${ }^{1}$ Pedro Skvarca, ${ }^{2}$ Yukari Takeuchi ${ }^{3}$ \\ ${ }^{1}$ Institute of Low Temperature Science, Hokkaido University, Sapporo 060, Japan \\ ${ }^{2}$ Instituto Antártico Argentino, Cerrito 1248, 1010 Buenos Aires, Argentina \\ ${ }^{3}$ Nagaoka Institute of Snow and Ice Studies, NIED, Nagaoka, Niigata 940, Japan
}

\begin{abstract}
Glaciar Upsala, a freshwater calving glacier in southern Patagonia, has been retreating since 1978, and after a drastic recession of about $700 \mathrm{~m} \mathrm{a}^{-1}$ in 1994 the retreat seems to have stopped in 1995 . A large ice-thinning rate of $11 \mathrm{~m} \mathrm{a}^{-1}$ was obtained between 1990 and 1993, by surveying surface elevations near the terminus of Glaciar Upsala. In 1993-94, the thinning was estimated at about $20 \mathrm{~m} \mathrm{a}^{-1}$ near the lateral margin. Some possible causes of the thinning behavior are considered.

In the ablation area of Glaciar Perito Moreno, $50 \mathrm{~km}$ south of Glaciar Upsala, ablation rates were measured during $110 \mathrm{~d}$ in summer 1993-94, and air temperature was continuously recorded throughout 1994 . Using a degree-day method with temperature data at the nearest meteorological station, Calafate, annual ablation during the last 30 years was estimated to fluctuate from about $12 \pm 2$ to $16 \pm 2 \mathrm{ma}^{-1}$ in ice thickness, with a mean of $14 \pm 2 \mathrm{~m} \mathrm{a}^{-1}$. Thus, the temperature anomaly alone cannot elucidate the thinning of $11 \mathrm{~m} \mathrm{a}^{-1}$ at Glaciar Upsala. As a possible mechanism of the ice-thinning, it is suggested that the considerable retreat due to calving may have resulted in reduction of longitudinal compressive stress exerted from bedrock rises and islands near the glacier front, causing a considerable decrease in the emergence flow. Thus, the ice may have thinned at a rate close to the annual ablation rate.
\end{abstract}

\section{INTRODUCTION}

It is known that calving glaciers advance and retreat in a different way from glaciers on dry land (Mercer, 196l) and sometimes exhibit dramatic instability (Meier and Post, 1987). Glaciar Upsala, a large freshwater calving glacier in southern Patagonia, has recently shown rapid retreat, fast flow and considerable thinning of ice. This paper presents the recent behavior of Glaciar Upsala until 1995, and considers some possible causes of the ice-thinning, including recent climate trends, annual ablation rates and glacier dynamics.

Numerous outlet glaciers discharge from the two ice fields in Patagonia, the larger of which is Hielo Patagónico Sur (HPS; southern Patagonia ice field) with an area of $13000 \mathrm{~km}^{2}$ (Fig. 1). Almost all outlet glaciers of HPS calve into fjords on the Pacific side and into lakes on the inland side. Information compiled from various sources, including satellite data and air photographs, shows that most glaciers in HPS have retreated considerably during the last half-century. For example, Glaciares Tyndall, Upsala and O'Higgins retreated more than $3 \mathrm{~km}$ during 41 years from 1945 (Aniya and others, 1992; Naruse and others, 1995). On the other hand, Glaciar Pio XI (or Brüggen) advanced about $10 \mathrm{~km}$ during the same period (Warren and Rivera, 1994), and Glaciar Perito Moreno has been almost in a steady state (Aniya and Skvarca, 1992; Skvarca and Naruse, 1997).

From 1983 to 1990 , large thinning rates were measured at Patagonian glaciers from surveys of surface elevations in the ablation areas: $5.2 \mathrm{ma}^{-1}$ at Glaciar Soler (Aniya and Naruse, 1987) and $4.0 \mathrm{~m} \mathrm{a}^{-1}$ at Glaciar Tyndall (Kadota and others, 1992). Field studies on thickness change have continued from 1990 to 1996 at Glaciares Tyndall, Upsala and Perito Moreno (Naruse and Aniya, 1995). Also flow velocities were measured at Glaciar Upsala, being $3.6 \mathrm{~m} \mathrm{~d}^{-1}$ in November 1990 (Naruse and others, 1992) and $4.4 \mathrm{~m} \mathrm{~d}^{-1}$ in November 1993 (Skvarca and others, 1995b) near the glacier terminus.

Glaciar Upsala flows southward from the eastern part of HPS, and calves into Brazo Upsala, a western channel of Lago Argentino (Fig. 1), at an elevation of about $180 \mathrm{~m}$ a.s.l. around $49^{\circ} 58^{\prime} \mathrm{S}$ and $73^{\circ} 17^{\prime} \mathrm{W}$. Clear medial moraines can be recognized along the center line, of about $3 \mathrm{~km}$ wide ablation area near the terminus. The eastern part of the ice body is fed from the ice field south of the Upsala-Viedma divide, while the western part is mostly fed from Glaciar Bertacchi. At the eastern lobe of Glaciar Upsala (Upsala east), calving rates and flow velocities were measured in March 1992 (Warren and others, 1995). The surface of the ablation area of Upsala is heavily crevassed, with few debris covers. Preliminary measurements of water depth were made near the glacier front in Brazo Upsala, indicating large undulations from about 150 to $500 \mathrm{~m}$ in depth (personal communication from H. Svetaz, 1995). Based on these data and the surface topography of the glacier, it is considered that the frontal parts have been landed, not afloat, in the western section for at least the last 10 years and in the eastern section very recently.

\section{FRONTAL FLUCTUATIONS}

Front positions of Glaciar Upsala since 1945 are known on 


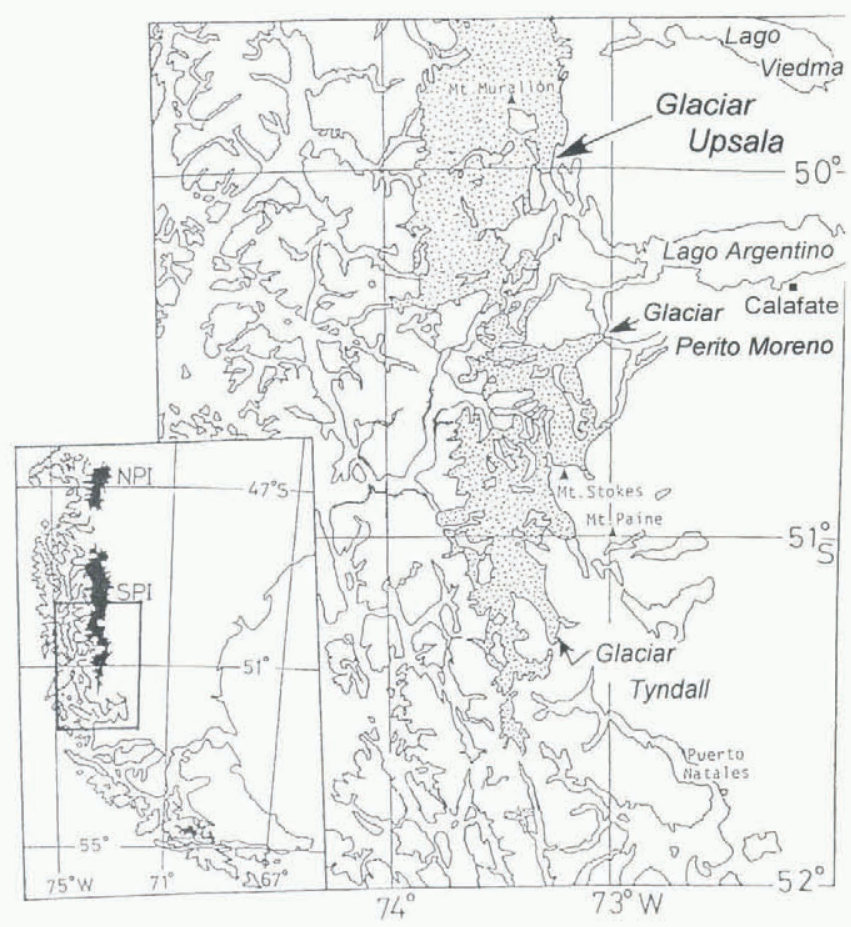

Fig. 1. Map showing the locations of studied glaciers in the southern part of Hielo Patagónico Sur, South America. The meteorological station Lago Argentino is located at Calafate.

the basis of topographic maps, air photographs and satellite data (Aniya and Skvarca, 1992; Aniya and others, 1992; Skvarca and others, 1995a, b). Recent positions of the glacier front are shown in Figure 2. A large retreat can be noted between November 1993 and December 1994. This drastic calving retreat may have occurred in mid-1994. Since early August 1994, a number of icebergs and blocks in Brazo Upsala have prevented tourist boats from approaching glaciers in the area (personal communication from L. Mansilla, 1994). In December 1994, Brazo Upsala was totally covered by icebergs and broken ice for a length of about $12 \mathrm{~km}$ (Skvarca and others, 1995a).

Fluctuations in the annual retreat rate averaged over the front margin of Upsala during the last half-century are shown in Figure 3. The retreat started in 1978 and a large retreat of about $700 \mathrm{~m} \mathrm{a}^{-1}$ occurred in 1994. Since December 1994, the retreat seems to have stopped.

\section{THINNING RATES}

Surface elevations along a transverse line near the terminus of Glaciar Upsala were measured on 14 November 1990 and 21 November 1993. The survey line stretched over about $1.5 \mathrm{~km}$ from the eastern margin to the medial moraines. From the difference in surface elevations between two measurements, change in ice thickness along the survey line can be obtained.

A control point ("cp" in Fig. 2) and an azimuth point were set up during the 1990 survey at about $315 \mathrm{~m}$ a.s.l. on the eastern bank near the glacier front (Naruse and others, 1992). An electronic distance meter (Topcon EDM-Theodolite) was utilized at the control point, and a reflector was placed at survey points on the glacier. In 1993, surface elevations at seven points with the same horizontal coordinates as in 1990 were measured.

Distributions of annual thickness change rate are plotted along the transverse distance in Figure 4. As a reference, results at Glaciares Tyndall and Perito Moreno are also shown. Thinning rate from 1990 to 1993 at Glaciar Upsala decreased from $14 \mathrm{~m} \mathrm{a}^{-1}$ near the margin to $9.5 \mathrm{~m} \mathrm{a}^{-1}$ in the central part, the mean being $11.1 \mathrm{~m} \mathrm{a}^{-1}$. At the flat surface area close (about $250 \mathrm{~m}$ distance) to the eastern margin, a remarkably large thinning rate of about $20 \mathrm{~m} \mathrm{a}^{-1}$ was estimated between November 1993 and December 1994. The larger thinning rate near the margin may have been caused by the enhanced melting rate of ice near the bare rock. At Glaciar Tyndall a mean thinning rate of $3.1 \mathrm{ma}^{-1}$ was obtained, whereas at Glaciar Perito Moreno the mean was $0.2 \mathrm{~m} \mathrm{a}^{-1}$, indicating a nearly stable condition.

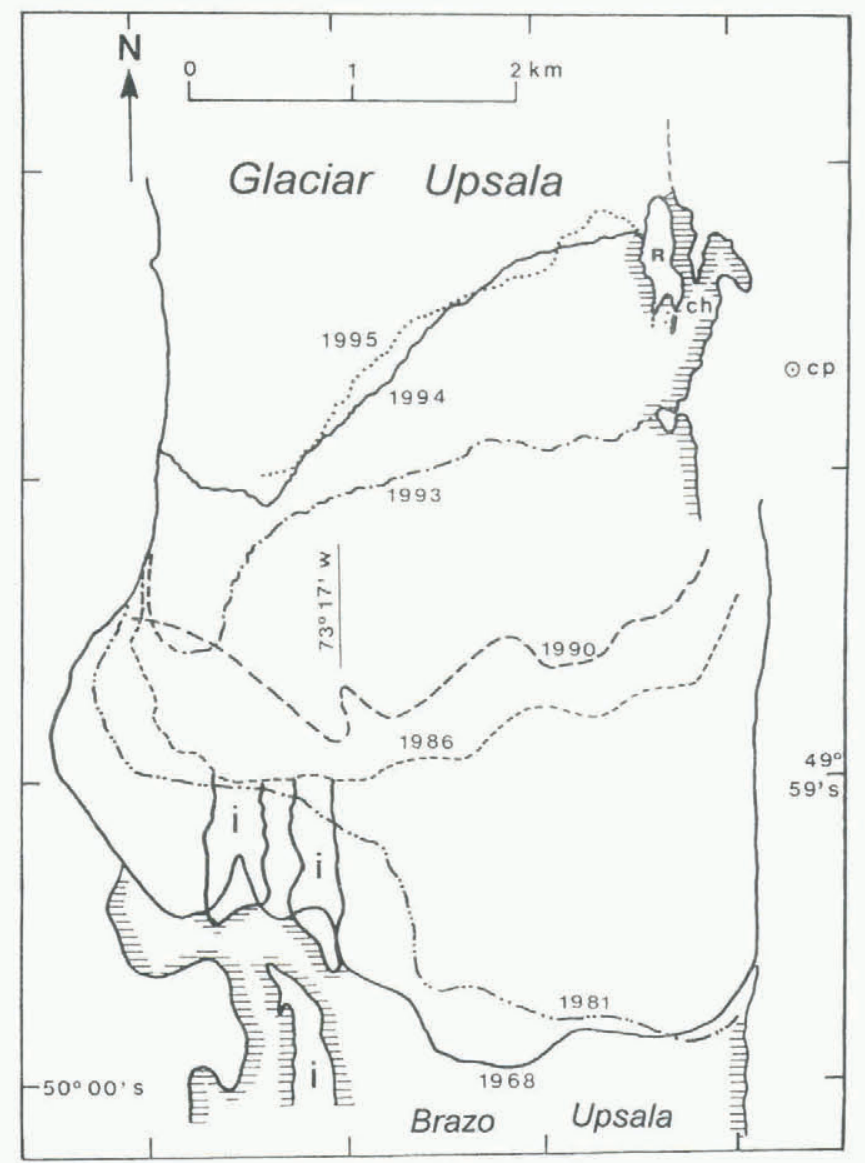

Fig. 2. Front margins of Glaciar Upsala. The front positions of 1968 (November) and 1981 (February) were determined by vertical aerial photographs, and that of 1986 (January) by Landsat thematic mapper (Aniya and Skvarca, 1992). The 1990 (November) position is based on observation from the eastern bank and the proglacial lake, which has been modified from the front position shown by Aniya and Skvarca (1992). The 1993 (November), 1994 (December) and 1995 (December) positions of the front and the eastern margin were measured by conventional angle surveys from the control point (cp) on the eastern bank to prominent points at the terminus, and also by global positioning system (Trimble Pathfinder Basic receivers) surveys at some points on the ice/rock boundary. $\mathrm{R}$ indicates a bare-rock ridge seen along the eastern glacier margin in 1993, that was almost covered with ice in 1990; ch indicates a lateral water channel; and i indicates an island as seen in 1986 at the glacier front. The survey line of surface profiles (Fig. 4) in 1990 and 1993 was located between the 1993 and 1994 front margins, being therefore now (1996) in the lake off the glacier. 


\section{DISGUSSION}

\section{Recent climatic trends}

There are no meteorological stations in the glacier region of Patagonia. The nearest station, where a long meteorological record is available since 1937, is Lago Argentino (220 m a.s.l.) at Calafate, about $80 \mathrm{~km}$ southeast of the front of Glaciar Upsala (Fig. 1).

According to an analysis by Ibarzabal y Donángelo and others (1996), during the last 50 years the annual mean air temperature at Calafate has increased by about $0.5^{\circ} \mathrm{C}$ from $7.2^{\circ} \mathrm{C}$, and the annual precipitation has decreased from about $220 \mathrm{~mm}$ to $180 \mathrm{~mm}$. Extremely low precipitation values have been found in recent years: $82 \mathrm{~mm} \mathrm{a}^{-1}$ in 1986 and $60 \mathrm{~mm} \mathrm{a}^{-1}$ in 1988. Also, a positive trend of temperature is seen to be more pronounced at Rio Gallegos $\left(52^{\circ} \mathrm{S}\right.$, $69^{\circ} \mathrm{W}$ ) on the Atlantic coast. However, these trends are not dominant over the whole region to the east of HPS; for example, there is a weak warming trend and increasing precipitation at San Julián $\left(49^{\circ} \mathrm{S}, 68^{\circ} \mathrm{W}\right)$ on the coast, and nearly stable conditions of temperature and precipitation at Puerto Deseado $\left(48^{\circ} \mathrm{S}, 66^{\circ} \mathrm{W}\right)$ on the coast.

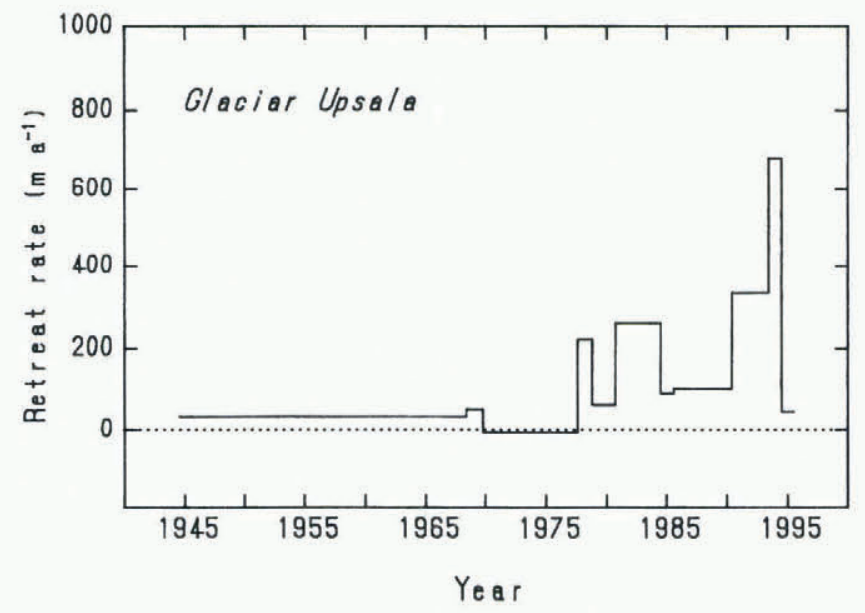

Fig. 3. Fluctuations in the retreat rate of the Glaciar Upsala front during the last half-century. In 1994 a large retreat occurred which stopped in 1995. Data sources: Aniya and others (1992) for 1945-68, Aniya and Skvarca (1992) for 1968-90, Skvarca and others (1995b) for 1990-93, and the present study for 1993-95.

Since Calafate is located in a different climate (semi-arid condition) from that in the glacier region, a detailed and quantitative discussion is not possible on the relationship between variations of glaciers and climate. However, the warming trend tends to increase the ablation rate, and the decreasing trend in precipitation tends to decrease the surface net mass balance and to decrease the albedo of the ablation area in winter. Therefore, recent climate trends observed at Calafate should have affected somewhat, though the magnitude is uncertain, the recent thinning of Glaciar Upsala.

\section{Estimate of annual ablation}

At Glaciar Perito Moreno, $50 \mathrm{~km}$ south of Upsala, ablation rates were measured with $10 \mathrm{~m}$ long aluminum poles (in $2 \mathrm{~m}$ sections) throughout the summer of 1993-94 (Naruse and others, 1995). The mean ablation obtained from four sites around $350 \mathrm{~m}$ a.s.l. was $7.0 \mathrm{~m}$ ice thickness (6.3 m w.e.) over a period of $110 \mathrm{~d}$. Continuous, annual records of air temperature were first measured at two sites around the lower reach of Glaciar Perito Moreno from November 1993 to December 1994 (Takeuchi and others, 1996). An empirical linear relationship was derived between the total ablation and the cumulative daily mean air temperature (positive degree days: PDDs) during the $110 \mathrm{~d}$. A ratio $k$ between the two quantities was obtained, of $7.1 \mathrm{~mm}$ w.e. ${ }^{\circ} \mathrm{C}^{-1} \mathrm{~d}^{-1}$. Although the parameter $k$ should change with the seasons, especially when the bare ice is covered with new snow, we assume here it is constant throughout the year and from year to year.

Throughout the year December 1993-November 1994, the relationship of daily mean air temperatures at Glaciar Perito Moreno and the station at Calafate, about $60 \mathrm{~km}$ east of the glacier front, was examined. It was found that the mean temperature at the glacier is lower than at Calafate by $2.3^{\circ} \mathrm{C}$ during the warm season (October-June), and higher by $0.4^{\circ} \mathrm{C}$ during the cold season (July-September). For each season, a good linear relationship was obtained between the two sites, with a correlation coefficient of 0.93 and 0.89 , respectively. We assume these relationships to be valid for monthly mean temperature and for other years.

Then, monthly mean temperatures at Calafate were translated into those at the glacier, and annual PDDs during the last 30 years were calculated. Using the PDD and parameter $k$, year-to-year variations in the annual amount of ablation at $350 \mathrm{~m}$ a.s.l. of Glaciar Perito Moreno were obtained from 1962 to 1994, as shown in Figure 5.

It is difficult to evaluate properly the error involved in the estimated annual ablation. However, assuming roughly an error in the parameter $k$ of $\pm 10 \%$ and an error in the rectified daily mean temperature of $\pm 1{ }^{\circ} \mathrm{C}$, the error in annual ablation is calculated as about $\pm 1.5 \mathrm{~m}$. Adding other possible errors to the value, the total error may be estimated as $\pm 2 \mathrm{~m}$. Then, a mean annual ablation during the 30 years is obtained, of about $14 \pm 2 \mathrm{~m}$ ice thickness, with a maximum ablation of $16 \pm 2 \mathrm{~m}$ ice in 1993 and a minimum of $12 \pm 2 \mathrm{~m}$ ice in 1971 .

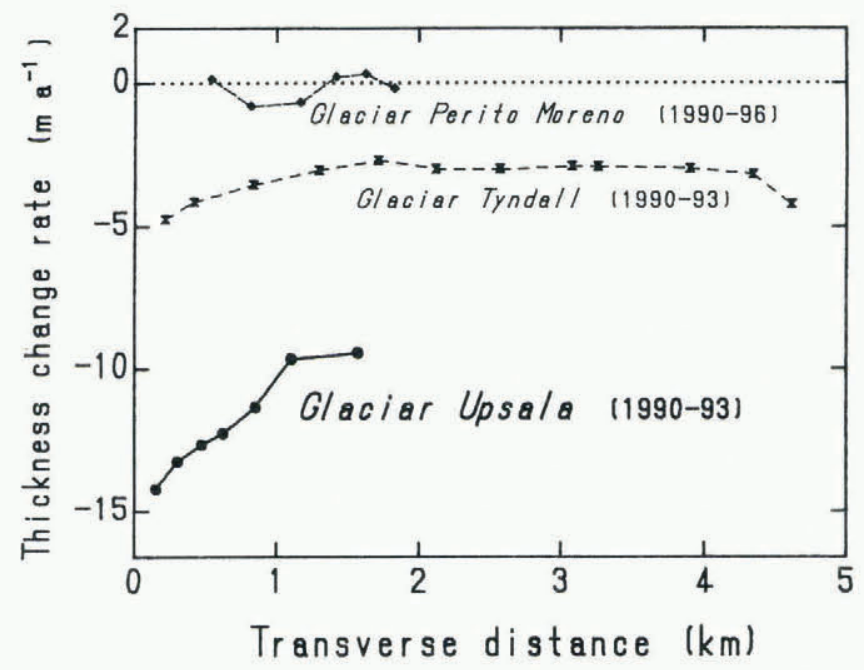

Fig. 4. Distributions of annual thickness-change rate along the transverse lines from the lateral margins of Glaciares Upsala (Skvarca and others, 1995b), Tyndall (Nishida and others, 1995) and Perito Moreno (Naruse and others, 1995; Skvarca and Naruse, 1997). The negative sign indicates thinning and the positive sign thickening. 
The elevation of the survey line at Glaciar Upsala is about $250 \mathrm{~m}$ a.s.l. Though no measurement of the surface albedo was made on this glacier, the color and whiteness of surface ice seemed to be almost the same as at Glaciar Perito Moreno where the albedo ranged from 0.2 to 0.4 (Takeuchi and others, 1995). If we assume the same $k$ value for the two glaciers, an enhanced annual ablation due to a lower elevation of $100 \mathrm{~m}$ at Glaciar Upsala is given, of about $2 \mathrm{~m}$. So, mean annual ablation during 30 years at Glaciar Upsala is estimated as about $16 \pm 2 \mathrm{~m}$ ice thickness, with $18 \pm 2 \mathrm{~m}$ ice as a maximum and $14 \pm 2 \mathrm{~m}$ ice as a minimum.

Thus, a range between the maximum and minimum annual ablation caused by year-to-year variations in air temperature can be considered as about $4 \pm 3 \mathrm{~m}$ ice thickness, which is much smaller than the measured ice thinning. It is concluded that the change in temperature alone cannot elucidate the thinning rate of $11 \mathrm{ma}^{-1}$ at Glaciar Upsala. Changes in precipitation in winter (albedo effect) or the amount of cloud cover in summer may also greatly influence the ablation rate.

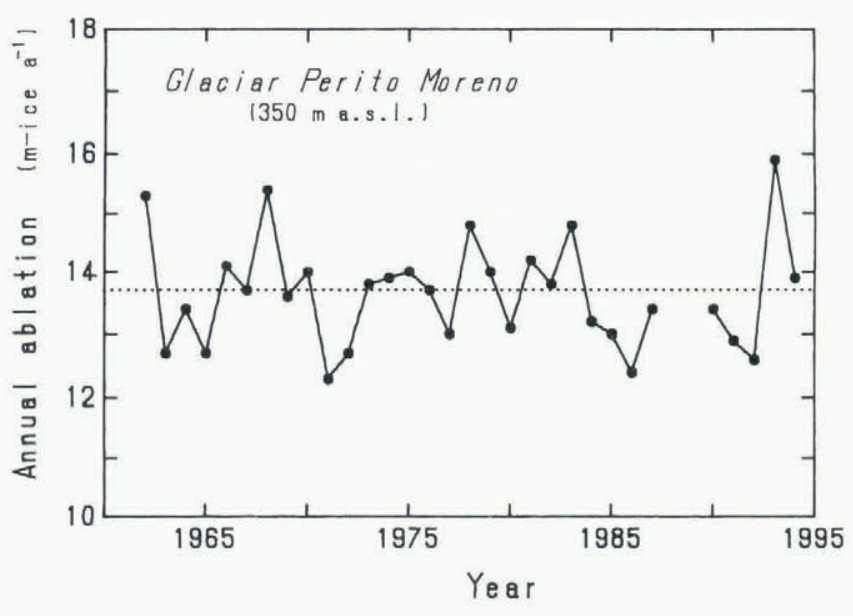

Fig. 5. Variations in the annual amount of ablation ( $m$ ice thickness) at about $350 \mathrm{~m}$ a.s.l. in Glaciar Perito Moreno, estimated from the temperature data at Calafate during the last 30 years.

\section{Dynamical features of thinning of Glaciar Upsala}

The thickness change during a year at the ablation area of a glacier results from the difference between the annual emergence velocity and the annual net ablation rate (negative annual surface net mass balance). Near the terminus of Glaciar Upsala, a thinning rate of $11 \mathrm{~m} \mathrm{a}^{-1}$ was obtained and a total ablation rate of $16 \pm 2 \mathrm{~m}$ ice thickness was estimated. The total ablation is the sum of the net ablation and the melting amount of snow accumulation. Monthly mean air temperature in the coldest month (June) was measured as $+0.3^{\circ} \mathrm{C}$ at Glaciar Perito Moreno (Takeuchi and others, 1996). Based on precipitation data at Calafate, it is presumed that the ablation area of the glacier is intermittently covered with new snow during the period May-August. If we assume snow accumulation near the glacier terminus to be on the order of 2 or $3 \mathrm{~m} \mathrm{a}^{-1}$, the emergence velocity is also on the order of 2 or $3 \mathrm{~m} \mathrm{a}^{-1}$, which is very small compared with the annual net ablation.

The emergence flow is caused by the longitudinal compression of ice due to a longitudinal compressive stress in a parallel-sided valley glacier, as is the case of the lower part of Glaciar Upsala. The very small emergence component near the Upsala terminus indicates that the glacier is moving almost without deformation; the ice body is sliding with a very high velocity of around $4 \mathrm{~m} \mathrm{~d}^{-1}$ (in November 1990 and 1993). Due to the existence of abundant water in the lateral margins as well, the side drag is also considered to be very low. The very small longitudinal compressive stress near the terminus may have resulted from a considerable reduction in backstress from bedrock rises and islands near the front, after the large retreat.

Similar behaviors of glacier retreats are found in Cordillera Darwin and Alaska. According to Holmlund and Fuenzalida (1995), prior to 1943 there was a slight retreat of glaciers along the northern side of Cordillera Darwin, and over the last two decades the north-facing glacier Ventisquero Marinelli has retreated several hundred meters per year. The authors considered the dramatic recession to be only partly a response to climatic changes, and mainly due to the local topography. With respect to tidewater glaciers, Meier and Post (1987) stated a feedback, in that retreat decreases back-pressure on the glacier, increasing its stretching and velocity, and causing thinning, which decreases the effective pressure on the bed, causing further increase in stretching and further increase in calving. Having analyzed data from Columbia Glacier (Alaska), Van der Veen (1986) pointed out that the calving rate is not simply linked to observed quantities such as water depth or stretching rate near the terminus. He suggested that, during the retreat, thickness at the terminus appears to be linearly correlated with water depth; at the terminus, the thickness in excess of flotation remained at about $50 \mathrm{~m}$. Venteris and others (1997) conclude that, for the dynamics of Columbia Glacier, backstress from the shoal and island at the end of the fjord is not important; rather, terminal position is determined by ice thickness which, in turn, is primarily determined by the rate of longitudinal stretching.

Due to scarce data at Glaciar Upsala, we cannot compare its behavior with that of Columbia Glacier. An interesting problem remains unsolved: of retreat and thinning, which is the cause and which is the effect of the shrinkage of Glaciar Upsala?

\section{CONCLUSION}

The large thinning rate of $11 \mathrm{~m} \mathrm{a}^{-1}$ measured at Glaciar Upsala cannot be elucidated by temperature change alone. We propose a scenario for the thinning and retreat. Retreat of the glacier started in the late 1970 s, probably independently of climatic changes. Retreat of the front has reduced the backstress from the frontal part of the glacier. Due to a low compressive stress, the emergence flow decreased considerably. As a result, large thinning of ice has occurred with a magnitude close to the annual net ablation.

\section{ACKNOWLEDGEMENTS}

We express our gratitude to R. Chiocconi and T. Toconás for their help during field campaigns in 1994 and 1995. Thanks are due also to all the personnel of Destacamento Naval Reforzado Punta Bandera - Prefectura Naval Argentina, Compañia Hielo y Aventura, and Intendencia Parque Nacional los Glaciares-Administración de Parques 
Nacionales, for their efficient logistic support. Meteorological data at Calafate were provided by the Servicio Meteorológico Nacional, Argentina, for which we would like to thank Director Técnico G. Talamoni and T. Ibarzabal y Donángelo. Thanks are also due to M. Aniya for helpful discussion, J. Kuylenstierna for useful comments, and an anonymous referee for pointing out the similarity with a glacier in Cordillera Darwin. This study was partly supported by grants under the International Scientific Research Program (Nos. 02041004 and 05041049) of the Monbusho, Japan.

\section{REFERENCES}

Aniya, M. and R. Naruse. 1987. Structural and morphological characteristics of Soler Glacier, Patagonia. Bull. Glacier Res. 4, 69-77.

Aniya, M. and P. Skvarca. 1992. Characteristics and variations of Upsala and Moreno glaciers, southern Patagonia. Bull. Glacier Res. $10,39-53$.

Aniya, M., R. Naruse, M. Shizukuishi, P. Skvarca and G. Casassa. 1992. Monitoring recent glacier variations in the southern Patagonia ice field, utilizing remote sensing data. Int. Arch. Photogramm. Remote Sensing, 29 (B7), 87-94

Holmlund, P. and H. Fuenzalida. 1995. Anomalous glacier responses to 20th century climatic changes in Darwin Cordillera, southern Chile. 7 . Glaciol., 41(139), 465-473.

Ibarzabal y Donángelo, T., J. A. J. Hoffmann and R. Naruse. 1996. Recent climate changes in southern Patagonia. Bull. Glacier Res. 14, 29-36.

Kadota, T., R. Naruse, P. Skvarca and M. Aniya. 1992. Ice flow and surface lowering of Tyndall Glacier, southern Patagonia. Bull. Glacier Res. 10, $63-68$.

Meier, M. F. and A. Post. 1987. Fast tidewater glaciers. 7. Geophys. Res., 92(B9), 9051-9058.
Mercer, J. H. 1961. The response of fjord glaciers to changes in the firn limit. 7. Glaciol., 3(29), 850-858.

Naruse, R. and M. Aniya. 1995. Synopsis of glacier researches in Patagonia, 1993. Bull. Glacier Res. 13, 1-10.

Naruse, R., P. Skvarca, T. Kadota and K. Koizumi. 1992. Flow of Upsala and Moreno glaciers, southern Patagonia. Bull. Glacier Res. 10, 55-62.

Naruse, R., M. Aniya, P. Skvarca and G. Casassa. 1995. Recent variations of calving glaciers in Patagonia, South America, revealed by ground surveys, satellite-data analyses and numerical experiments. Ann. Glaciol, 21, 297-303.

Nishida, K., K. Satow, M. Aniya, G. Casassa and T. Kadota. 1995. Thickness change and flow of Tyndall Glacier, Patagonia. Bull. Glacier Res. 13 $29-34$.

Skvarca, P. and R. Naruse. 1997. Dynamic behavior of Glaciar Perito Moreno, southern Patagonia. Ann. Glaciol., 24 (see paper in this volume).

Skvarca, P., H. Rott and T. Nagler. 1995a. Drastic retreat of Upsala Glacier, southern Patagonia, revealed by ERS-1/SAR images and field survey. SELPER, 11 (1-2), 51-55.

Skvarca, P., K. Satow, R. Naruse and J. C. Leiva. 1995b. Recent thinning, retreat and flow of Upsala Glacier, Patagonia. Bull. Glacier Res. 13, 11-20.

Takeuchi, Y., R. Naruse and K. Satow. 1995. Characteristics of heat balance and ablation on Moreno and Tyndall glaciers, Patagonia, in the summer 1993/94. Bull. Glacier Res. 13, 45-56.

Takeuchi, Y., R. Naruse and P. Skvarca. 1996. Annual air-temperature measurement and ablation estimate at Moreno Glacier, Patagonia. Bull. Glacier Res. 14, $23-28$.

Van der Veen, C. J. 1996. Tidewater calving. J. Glaciol., 42(141), 375- 385.

Venteris, E. R., I. M. Whillans and C. J.van der Veen. 1997. Effect of extension rate on terminus position, Columbia Glacier, Alaska, U.S.A. Ann. Glaciol., 24 (see paper in this volume).

Warren, C. R. and A. Rivera. 1994. Non-linear climatic response of calving glaciers: a case study of Pio XI Glacier, Chilean Patagonia. Revista Chilena de Historia Natural Pura y Aplicada, 67, 385-394.

Warren, C. R., D. R. Greene and N. F. Glasser. 1995. Glaciar Upsala, Patagonia: rapid calving retreat in fresh water. Ann. Glaciol., 21, 311-316. 